\title{
Human T Cell Leukemia Virus-I-associated T-Suppressor Cell Inhibition of Erythropoiesis in a Patient with Pure Red Cell Aplasia and Chronic Tr-Lymphoproliferative Disease
}

\author{
Lee J. Levitt, Gregory R. Reyes, Dilip K. Moonka, Klaus Bensch, Richard A. Miller, and Edgar G. Engleman \\ Departments of Medicine and Pathology, Stanford University Medical Center, Stanford, California 94305; Gene Labs, Inc., \\ Redwood City, California 94063; and Becton-Dickinson Monoclonal Center, Inc., Mountain View, California 94043
}

\section{Abstract}

Human retroviruses have recently been linked with $T$ cell lymphoproliferative disorders and with the acquired immune deficiency syndrome. We investigated the mechanisms for acquired pure red cell aplasia and cutaneous anergy in a patient with the chronic $\mathbf{T} \gamma$-lymphoproliferative disease (T $\gamma$-LPD) syndrome. Patient marrow erythroid progenitors (BFU-E) were $17 \pm 9 \%$ of control and were selectively increased to 88-102\% of control after marrow T cell depletion. Patient Leu $2+$ suppressor $\mathbf{T}$ cells spontaneously produced high titers of human $\boldsymbol{\gamma}$-interferon and resulted in a concentration-dependent selective inhibition (74-91\%) of BFU-E when co-cultured with autologous or allogeneic marrow. Conditioned media (CM) derived from patient Leu $2+T$ cells similarly inhibited growth of autologous or allogeneic marrow BFU-E. The inhibitory factor derived from patient $\mathrm{CM}$ was acid-labile ( $\mathrm{pH} 2$ ) and sensitive to trypsin; prior treatment of patient $T$ cells with anti-HLADR monoclonal antibody plus complement abrogated the suppressive effect of $T$ cell-derived CM. Patient peripheral blood mononuclear cells (PBMC) were unable to support growth of cultured interleukin 2 (IL 2)-dependent $T$ cells, but responded to exogenous IL 2 in vitro with a 16-21-fold augmentation, relative to control, in mitogen-induced proliferation. Antibodies to HTLV-I core proteins p19 and p24 but not to HTLV-III proteins were detected in patient serum by Western blotting; patient cultured PBMC stained (7-11\%) with antibodies to p19 and p24. Patient cultured PBMC demonstrated integrated HTLV-I genomic sequences by the Southern technique and expressed both specific HTLV-I genomic sequences by RNA dot blot plus reverse transcriptase activity. Utilizing a cloned DNA probe for the beta chain of the $T$ cell receptor gene, patient PBMC demonstrated gene rearrangements providing presumptive evidence for clonality. The presence in serum of HTLV-I p19 and p24 antibodies, the expression of p19 and p24 core antigens on patient mononuclear cells, the evidence of HTLV-I proviral integration sequences and the expression of HTLV-I genomic sequences in patient cells, indicates infection with HTLV-I and raises the possibility of an etiologic link between human retrovirus infection and some instances of large granular lymphocytic leukemia (T $\gamma$-LPD).

Address reprint requests to Dr. Levitt, Hematology Division, Stanford University Medical Center, Stanford, CA 94305.

Received for publication 2 October 1986 and in revised form 26 August 1987.

J. Clin. Invest.

(c) The American Society for Clinical Investigation, Inc. 0021-9738/88/02/0538/11 $\$ 2.00$

Volume 81, February 1988, 538-548

\section{Introduction}

Human retroviruses were first isolated in cultured cells derived from a patient with a variant of cutaneous $\mathrm{T}$ cell lymphoma (1). Leukemia/lymphomas associated with these viruses (human T cell leukemia virus, HTLV) ${ }^{1}$ are diseases of mature postthymic (peripheral) T lymphocytes $(2,3)$. Serologic, virologic, and epidemiologic criteria have most strongly associated a member of this retrovirus family, HTLV-I, with adult T cell leukemia $(4,5)$. A separate but related retrovirus, human immunodeficiency virus (HIV, formerly HTLV-III) can now also be recovered from over $90 \%$ of patients with early stages of the acquired immune deficiency syndrome (AIDS) (4). Recently a further group of patients has been described with a proliferation of morphologically mature $T$ lymphocytes. This syndrome, termed "chronic T cell lymphocytosis" or "chronic $\mathrm{T} \gamma$-lymphoproliferative disease," encompasses a distinct clinical, morphologic and immunologic entity (6-9). Patients with this syndrome have a proliferation of large granular activated lymphocytes (usually bearing suppressor-cytotoxic and natural killer surface antigenic determinants) associated with mild splenomegaly without adenopathy, a peripheral blood lymphocyte count which is usually less than 20,000 per cubic millimeter and only a modest marrow lymphocytic infiltration. The disorder is frequently accompanied by unexplained cytopenias, deficient lymphocyte responses to in vitro $T$ cell mitogenic stimulation, low or absent peripheral blood natural killer cell activity, and a variable defect in immunoglobulin production (6).

In this study we have investigated the mechanisms for acquired pure red cell aplasia and cutaneous anergy in a patient with the chronic $T$ cell lymphocytosis syndrome. Our results indicate in part that this patient possessed a number of independent markers for infection with HTLV-I, and that his red cell aplasia was mediated by a unique population of peripheral blood and marrow HLA-DR+ T suppressor lymphocytes capable of selective inhibition of both autologous and allogeneic erythropoiesis.

\section{Case Report}

A 61-yr-old heterosexual man was evaluated for a 2-mo history of anemia, reticulocytopenia, and mild lymphocytosis. A routine hemogram performed 9 mo earlier had indicated a hematocrit of $41 \%$ and a white-cell count of 8,400 with $34 \%$ neutrophils and $55 \%$ lymphocytes. There was no history of intravenous drug abuse or of recent exposure to any medications known to cause anemia or red cell aplasia. The

1. Abbreviations used in this paper: BFU-E, early erythroid burstforming units; CFU-GM, granulocyte-monocyte colony-forming units; CM, conditioned media; HBV, hepatitis B virus; HTLV, human T cell leukemia virus; LGL, large granular lymphocytes; NK, natural killer cells; $\mathrm{T}_{\boldsymbol{\gamma}}$-LPD, T-gamma lymphoproliferative disease. 
patient had received $3 \mathrm{U}$ of packed red blood cells $1.5 \mathrm{yr}$ earlier during treatment of an active duodenal ulcer; no lymphocytosis was demonstrated on hemograms performed at that time.

On physical examination the lymph nodes and liver were not enlarged. The spleen was palpable $2 \mathrm{~cm}$ beneath the left costal margin. The hematocrit was $24 \%$ with a mean corpuscular volume (MCV) of 98. The white-cell count was 6,800 per cubic millimeter with 27 per cent neutrophils, $68 \%$ lymphocytes and $5 \%$ monocytes. On smear, many of the lymphocytes appeared large with indented nuclei without nucleoli and with moderate amounts of cytoplasm containing small azurophilic granules. The reticulocyte count was $0.4 \%$ and the direct and indirect Coombs' test were negative. The platelet count was 316,000 per cubic millimeter. Bone marrow aspirate and biopsy demonstrated normocellularity (45\%) with normal myeloid maturation and adequate megakaryocytes. Marrow erythroid precursors were markedly diminished with an $\mathrm{M} / \mathrm{E}$ ratio of 20:1. Lymphocytes on each of four separate marrow biopsies over a span of 3 mo comprised $10-20 \%$ of the total marrow cellular population. Marrow cytogenetics were normal.

Whole body computed tomography (CT) scanning revealed moderate splenomegaly but no thymoma nor mediastinal or abdominal lymphadenopathy. The patient was anergic with absent delayed hypersensitivity cutaneous responses to tuberculin, candida, coccidioidin, and SKSD antigens. Serum immunoelectrophoresis revealed a normal configuration without monoclonal proteins but assessment of quantitative immunoglobulins demonstrated panhypogammaglobulinemia: IgG 353 mg\% (normal range, 800-1,800 mg\%), IgM 25 mg\% (45-250) and IgA $53 \mathrm{mg} \%(90-450)$.

The patient's hemogram and marrow biopsies remained unchanged over the ensuing three months; he was transfusion-dependent and required an average of three or four units of packed red blood cells per month. 3 mo after his initial evaluation he was begun on cyclophosphamide $100 \mathrm{mg}$ daily per mouth and prednisone $35 \mathrm{mg}$ daily per mouth. $8 \mathrm{wk}$ after initiation of therapy the patient's hematocrit had risen to $35 \%$ with a rise in the reticulocyte count to $4 \%$. The white-cell count was now 3600 per cubic millimeter with $61 \%$ neutrophils, $12 \%$ bands, $8 \%$ monocytes and only $19 \%$ lymphocytes; a repeat marrow aspirate revealed normal erythropoiesis. The patient's hematocrit over the ensuing 4 mo was maintained in the range of 34 to $40 \%$ despite cessation of cyclophosphamide and reduction of the prednisone dosage. 2 mo after cessation of cyclophosphamide, the patient's serum IgG had risen to $940 \mathrm{mg} \%$, IgM to $65 \mathrm{mg} \%$, and IgA to $110 \mathrm{mg} \%$. The patient remained anergic when reevaluated while on prednisone $15 \mathrm{mg}$ daily.

\section{Methods}

Blood and marrow samples. Heparinized blood and marrow aspirates were obtained from the patient and from normal adult donors after informed consent. All protocols were approved by the Stanford Medical Committee for the Use of Human Subjects in Research. Blood and marrow samples were diluted in medium and layered over Ficoll-Hypaque gradients (density, $1.077 \mathrm{~g} / \mathrm{cm}^{3}$ ), and mononuclear cells at the interface were collected after washing and centrifugation. Patient mononuclear cells were either assayed directly or cryopreserved in $10 \%$ dimethylsulfoxide and $30 \%$ fetal calf serum at $-196^{\circ} \mathrm{C}$ in liquid nitrogen until further study.

Assay systems for hematopoietic progenitors. Concentrations of $1.0-2.0 \times 10^{5}$ marrow mononuclear cells were cultured in the presence of $1 \mathrm{IU}$ of purified human urinary erythropoietin (1140 U per milligram of protein, National Institutes of Health) in triplicate 1-ml aliquots in methylcellulose cultures with or without $1 \%$ Mo conditioned medium (this medium, conditioned by a T-lymphoblast cell line, is a potent source of erythoid burst-promoting activity, $\mathrm{BPA}^{10}$ ). Cultures were incubated under $5 \% \mathrm{CO}_{2}$ in high humidity at $37^{\circ} \mathrm{C}$. Erythroid colony-forming units (CFU-E) were enumerated on day 7 and erythroid burst-forming units (BFU-E), granulocyte-macrophage progen- itors (CFU-GM), and multipotential hematopoietic stem cells [(CFUGEMM), colony-forming units giving rise to mixed colonies with granulocytic, erythroid, macrophage and megakaryocytic elements] were enumerated on days $12-14$ as previously described $(11,12)$. In selective experiments marrow mononuclear cells were co-cultured with either patient or control peripheral blood (PB) mononuclear cells at $\mathrm{PB}$ cell concentrations ranging from 1 to $15 \%$ of the total mononuclear cells in culture.

Monoclonal antibodies and analysis on the fluorescence-activated cell sorter (FACS). All monoclonal antibodies used in this study were ascites fluid produced by the methods of somatic cell hybridization and have been reported previously (13-18). Suspensions of blood or marrow mononuclear cells were first washed with staining medium and 2 $\times 10^{6}$ cells resuspended in $0.1 \mathrm{ml}$ containing the appropriate monoclonal antibody ( $1 \mu \mathrm{g}$ of antibody per $10^{6}$ cells) or control ascites diluent. Samples were incubated for $30 \mathrm{~min}$ at $0^{\circ} \mathrm{C}$, washed, and resuspended for $20 \mathrm{~min}$ with $0.1 \mathrm{ml}$ of rabbit anti-mouse affinity-purified fluorescein-conjugated immunoglobulin (Tago, Inc., Burlingame, CA). After washing, fluorescence intensity was determined for $3 \times 10^{4}$ viable cells from each suspension using a modified FACS IV (BectonDickinson Co., Oxnard, CA) equipped with dual lasers, two to three independent fluorescence detection systems, a small angle light detector and a propidium iodide detector. Background fluorescence was assessed with staining medium and/or control isotype identical ascites.

Cell separation procedures. Marrow or peripheral blood nonadherent buoyant (NAB) mononuclear cells were obtained after two consecutive 90 -min adherence procedures at $37^{\circ} \mathrm{C}$ as previously described (12); nonadherent cell suspensions were sometimes further depleted of monocytes by panning with Leu M3 monoclonal antibody (MCAb) (16). NAB cells obtained in this manner were $<2 \%$ monocytes by esterase staining and immunofluorescence labeling with Leu M3. Incubation conditions were developed as previously described (11) for assessing antibody-dependent complement-mediated cytotoxicity (utilizing either Leu 1 pan-T-cell MCAb or anti-HLA-DR [2.06] $\mathrm{MCAb}$ ) against human marrow or peripheral blood mononuclear cells.

Purified subsets of peripheral blood T cells and B cells were obtained by solid-phase immunoabsorption ("panning"): blood populations enriched for $T$ or non-T cells were first prepared by single-step rosetting using 2-amino-ethylisothiouronium bromide (AET)-treated sheep red blood cells (SRBC) (12). Cells recovered from the rosetted pellet (96-100\% Leu 1 positive) were coated with either pan-T Leu 1, T-helper-inducer Leu 3, or T-suppressor-cytotoxic Leu 2 MCAb and then added to petri dishes previously coated with goat antimouse IgG (indirect panning) $(12,19)$. Cells bound to the coated dishes and nonbound cells were separately recovered after a 70 -min incubation at $4^{\circ} \mathrm{C}$ by differential elution; purity of the positively and negatively selected cell fractions was assessed by cytofluorographic analysis. In essentially all cases $>95 \%$ of bound cells and $<5 \%$ of nonbound cells stained positively with the antibody used for panning (20). Peripheral blood nonrosetting mononuclear cells were similarly coated with pan-B Leu $12 \mathrm{MCAb}$ before indirect panning so as to obtain purified populations of B lymphocytes. Indirect panning with pan-T Leu $1 \mathrm{MCAb}$ was also utilized to deplete patient marrow mononuclear cells of $T$ lymphocytes. In all instances, colony growth was corrected for concentration enrichment following $T$ cell depletion, based upon per cent $T$ cells in control and T-depleted mononuclear cells (12).

Conditioned media were prepared at mononuclear cell concentrations of $10^{6}$ cells per $\mathrm{ml}$ with or without $2 \mu \mathrm{g} / \mathrm{ml}$ of PHA. Cells were incubated in Iscove's medium at $37^{\circ} \mathrm{C}$ for $2-7 \mathrm{~d}$, harvested, centrifuged, and tested at final concentration of $1-15 \%$ (vol/vol) against adherent or nonadherent $\mathrm{T}$ cell-depleted marrow target cells.

Functional assays. Mitogen stimulated proliferation of patient and control peripheral blood mononuclear cells was assessed in roundbottom microtiter wells as previously described (12) utilizing PHA (1 $\mu \mathrm{g} / \mathrm{ml}$ ), concanavalin A (Con A, $50 \mu \mathrm{g} / \mathrm{ml}$ ) or pokeweed mitogen (PWM, 1:100). Assays were performed in quadruplicate. In some experiments cells were cultured in the presence of either $10-100 \mathrm{U} / \mathrm{ml}$ of human recombinant interleukin 2 (Cetus Corp.) or in the presence of 
$10 \%$ interleukin 2-containing conditioned medium (21). Patient peripheral blood mononuclear cells were also assessed for their ability to support growth of interleukin 2-dependent HT-2 cell lines (21). In these experiments patient cells $\left(10^{6}\right.$ cells per $\left.\mathrm{ml}\right)$ were incubated with 1 $\mu \mathrm{g} / \mathrm{ml}$ PHA, with or without an equal number of allogeneic irradiated Epstein-Barr Virus (EBV)-transformed lymphoid cells, for $48 \mathrm{~h}$ at $37^{\circ} \mathrm{C}$. Serial twofold dilutions of the culture supernatants were added to the HT-2 murine cell line and $\left[{ }^{3} \mathrm{H}\right]$ thymidine incorporation was utilized to assess supernatant interleukin 2 activity. An assay for natural killer (NK) activity was performed using K562 target cells and patient blood mononuclear cells at effector: target ratios varying from 5:1 to $100: 1$ as previously described (15); NK activity was assessed following either a 4 -h or an 18 -h incubation at $37^{\circ} \mathrm{C}$.

Patient and control blood mononuclear cells $\left(3 \times 10^{6}\right.$ cells per $\mathrm{ml}$ with or without $50-100 \mu \mathrm{g} \mathrm{ml}$ of Con A) were cultured for $72 \mathrm{~h}$ at $37^{\circ} \mathrm{C}$ and the resultant conditioned media were tested for gamma interferon activity by a cytopathic-effect-inhibition assay using vesicular stomatitis virus on WISH cells; results were compared against a laboratory gamma interferon standard (22).

Viral immunofluorescence and molecular hybridization. Antibodies to human T cell leukemia virus membrane antigens (HTLV-MA) were assayed via indirect living cell immunofluorescence as previously described (23) except that a fluorescence-activated cell sorter was utilized to determine percentage of cells fluorescing. Two reference HTLV-infected cell cultures (Hut 102 and MT 2) were used as well as two control HTLV-uninfected human lymphoid cell lines (8402, a T cell line and NC37, a B cell line positive for the Epstein-Barr virus genome). Patient serum samples were assessed twice, 3 mo apart, and samples were judged positive if a 1:4 dilution caused at least $50 \%$ fluorescence on target cells. Patient serum samples were also assessed by radioimmunoprecipitation with $\left[{ }^{35}\right.$ S]methionine-labeled Hut 102 cells as previously described (23). In further experiments, patient serum was tested for antibody to HTLV-I, HTLV-II, and HIV by Western blot assay (24). Serum samples were tested at a 1:100 dilution. Banding patterns of antibody were compared with those of a control serum mixture reactive with HTLV-I, II, and HIV, diluted 1:4000.

Patient fresh and cultured peripheral blood mononuclear cells were assessed for presence of HTLV core antigens using goat antibody to HTLV p $24^{25}$ and mouse monoclonal antibody against HTLV p $19^{26}$ in an indirect cytofluorographic immunofluorescence assay; stained cells were assessed by two and three-color flow cytometry as previously described $(12,15)$. In some experiments patient or control blood mononuclear cells $\left(10^{6}\right.$ cells per $\left.\mathrm{ml}\right)$ were placed into culture containing medium with $15 \%$ fetal calf serum, and $15-40 \%$ interleukin 2-containing medium with or without $0.001-0.01 \%$ phytohemagglutinin. Cultures were incubated at $37^{\circ} \mathrm{C}$ in $5 \% \mathrm{CO}_{2}$ for $1-4$ wk before assessment. In some instances, cell pellets were prepared from cultured cells fixed in $3 \%$ buffered gluteraldehyde, rinsed, then osmicated, dehydrated and embedded in epoxy plastic $(27,28)$. Ultrathin sections were stained with lead plus uranyl salts and examined in an Elmiskop 101 electron microscope.

Patient cultured peripheral blood mononuclear cells were analyzed for the expression of HTLV-I genomic sequences by RNA dot blot. Cell samples $\left(3 \times 10^{6}\right)$ were solubilized in $50 \mathrm{mM} \mathrm{Na}$ acetate buffer (pH 4.8) with $1.0 \%$ SDS before extraction with an equal volume of $60^{\circ} \mathrm{C}$ phenol (equilibrated in $50 \mathrm{mM} \mathrm{Na}$ acetate buffer). The aqueous phase was removed, and 0.1 volume of $3 \mathrm{M} \mathrm{Na}$ acetate buffer ( $\mathrm{pH}$ 6.0) added before precipitation with two volumes of $100 \%$ ethanol. RNA was collected by microcentrifugation and the pellets washed with $70 \%$ ethanol. Pellets were resuspended in $50 \mu 1$ DEPC-treated deionized water followed by addition of $30 \mu 120 \times$ SSC and $20 \mu 137 \%$ formaldehyde. After a 15 -min incubation at $60^{\circ} \mathrm{C}$ the samples were dot blotted with a (Bio-Rad Laboratories, Richmond, CA) microfiltration device. Hybridization was performed as outlined (29). A DNA fragment derived from the envelope region of a HTLV-I molecular clone (kindly provided by $\mathrm{F}$. Wong-Staal) was nick-translated with $\left[{ }^{32} \mathrm{P}\right]$ deoxynucleotide (specific activity $10^{8} \mathrm{dpm} / \mu \mathrm{g}$ ) and used as the hybridization probe.
In further experiments, patient cell DNA was assessed for the presence of integrated HTLV-I proviral genomic elements. $10 \mu \mathrm{g}$ of extracted cellular DNA, was cleaved with Eco RI or Bam HI, electrophoresed on a $0.75 \%$ agarose gel and transferred to nitrocellulose by the method of Southern (30). The filter was prehybridized and hybridized (31) using a ${ }^{32} \mathrm{P}$-nick translated HTLV-I-specific probe (pX region, provided by Drs. Wong-Staal and Gallo). In other experiments genomic blot hybridizations were performed with extracted DNA from patient cells and control cells used a ${ }^{32} \mathrm{P}$-nick translated probe for the beta chain of the T cell receptor (32).

Spent supernatants $(9-10 \mathrm{ml})$ derived from cultured patient mononuclear cells and from controls were pelleted at $100,000 \mathrm{~g}$ for $90 \mathrm{~min}$ at $4^{\circ} \mathrm{C}$ and subsequently assayed for reverse transcriptase activity according to published methods (33).

\section{Results}

Surface immunophenotypic analysis of patient peripheral blood and marrow mononuclear cells. The surface antigenic phenotype of fresh patient peripheral blood mononuclear cells was assessed on three separate occasions, prior to therapy, via indirect immunofluorescence with monoclonal antibodies using a three-color fluorescence-activated cell sorter. The patient's total white blood cell count on these occasions ranged from 5,800 to 10,100 per cubic millimeter with $64-77 \%$ lymphocytes. Greater than $90 \%$ of patient peripheral blood mononuclear cells coexpressed the pan-T-lymphocyte antigenic determinants Leu 4 and Leu 5, as well as the suppressor-cytotoxic determinant Leu 2. The pan-T determinant Leu 1 was expressed, although less intensely then Leu 4 or Leu 5 , on a majority of patient mononuclear cells. Patient peripheral blood helper-inducer (Leu 3) T cells (4\% of control) and B lymphocytes (Leu 12) (5\% of control) were both markedly diminished and the $T$ helper/T suppressor ratio $\left(T_{H} / T_{S}\right)$ was markedly inverted ( 0.05 , normal range 1.20 to 2.15$)$.

Virtually all peripheral Leu $2+$ cells failed to react with monoclonal antibody 9.3; the Leu $2+9.3-$ surface phenotype defines a $\mathrm{T}$ cell subset associated predominantly with immunoregulatory suppressor, as opposed to cytotoxic, activity (17). $71-75 \%$ of patient suppressor $T$ cells coexpressed antigenic determinants Leu 7 and Leu 11; Leu 7 is normally expressed on a subpopulation of peripheral blood $\mathrm{T}$ lymphocytes as well as on cells that express functional NK activity (15). The Leu 11 antigen is expressed on essentially all functional NK cells but has not been detected on monocytes, resting $\mathrm{T}$ cells, mitogenactivated T lymphoblasts or B cells (15). Anomalous expression of the Leu 11 determinant was also associated with evidence of $T$ cell activation; $48 \%$ of the patient's circulating $T$ cells expressed HLA-DR antigen, a surface determinant often found on activated $\mathrm{T}$ lymphocytes.

Cells staining positively for one or more of three separate fluoresceinated pan-T monoclonal antibodies (Leu 1, Leu 4, or Leu 5) comprised $15-26 \%$ of patient marrow nonadherent mononuclear cells. ( $\mathrm{T}$ cells comprise $7-12 \%$ of control marrow nonadherent mononuclear cells in our laboratory). Patient marrow lymphocyte cell surface antigenic determinants on each of two separate occasions were virtually identical to those expressed on circulating peripheral blood cells. Despite coexpression of the NK determinants Leu 7 and Leu 11, patient peripheral blood mononuclear cells demonstrated $<1 \%$ natural killer cell cytotoxic activity when assayed after either a 4- or 18-h incubation with chromium-labeled K562 target cells at effector:target cell ratios ranging from 5:1 to 100:1.

When reevaluated 2 mo after cessation of cyclophospha- 
mide and while in hematologic remission, the patient's white blood cell count was 3,600 per cubic millimeter with $61 \%$ neutrophils and only $19 \%$ lymphocytes. $72 \%$ of the patient's peripheral blood mononuclear cells expressed the pan- $T$ determinant Leu $4 ; 34 \%$ of cells expressed Leu 3 and $41 \%$ Leu 2 with a $T_{H} / T_{S}$ ratio of 0.83 . Only $9 \%$ of the patient's circulating T lymphocytes coexpressed the HLA-DR determinant.

Analysis of patient hematopoietic progenitors and effect of patient $T$ cells on autologous and allogeneic erythroid colony growth. Patient bone marrow mononuclear cells were plated in methylcellulose to assess growth of hematopoietic progenitors: normal values were found for granulocyte-macrophage CFUGM (49 \pm 5 , mean \pm S.D. per $1.5 \times 10^{5}$ cells plated) and multipotent CFU-GEMM $\left(21 \pm 2.5\right.$ per $10^{6}$ cells $)$. Patient early erythroid (BFU-E) progenitors were $17 \pm 9 \%\left(23 \pm 6\right.$ per $1.5 \times 10^{5}$ cells plated) of concurrent controls. Similar decrements in patient BFU-E were observed in either the presence or in the absence of Mo conditioned medium, a potent source of burstpromoting activity (BPA). Patient erythroid colony-forming units (CFU-E), when evaluated after $7 \mathrm{~d}$ of in vitro marrow growth, were $34 \pm 11 \%$ of control. Patient serum, with or without an added source of complement, failed to inhibit either autologous or allogeneic BFU-E or CFU-GM (data not shown).

$\mathrm{T}$ cells comprised $1.5-3.5 \%$ of patient marrow mononuclear cells following either Leu 1 complement-mediated cytotoxicity or Leu 1 panning, and $<1.0 \%$ of marrow mononuclear cells following Sepharose column immunoabsorption with a combination of Leu 1 plus Leu 4 monoclonal antibodies. $T$ cell depletion of patient marrow produced a selective increase in BFU-E after incubation with Leu 1 pan-T monoclonal antibody plus complement ( $88 \pm 6 \%$ of control) or after marrow "panning" with Leu 1 (102 $\pm 10 \%$ of control) (Fig. 1). Indicated values for BFU-E following marrow $T$ cell depletion are corrected for progenitor cell enrichment based upon extent of marrow $\mathrm{T}$ cell removal. No increase in patient CFU-GM was observed following marrow $T$ cell depletion by either Leu 1 plus complement or panning.

Patient peripheral blood Leu 2+ mononuclear cells were next co-cultured with autologous $T$ cell-depleted bone marrow. Patient cells produced a selective concentration-dependent inhibition of autologous BFU-E (84\% inhibition of patient $\mathrm{T}$-free $\left(\mathrm{T}_{\mathrm{F}}\right)$ colony growth at a peripheral blood mononuclear cell concentration of $10 \%$, Fig. $2 \mathrm{~A}$ ). No inhibition of autologous BFU-E was seen after co-culture with control unseparated peripheral blood mononuclear cells, or control Leu $2+$ peripheral blood T cells (Fig. $2 A$ ). Patient mononuclear cells produced a similar degree of autologous in vitro BFU-E inhibition both in the presence and absence of burst-promoting activity (Mo conditioned medium) and both before and after adherent depletion of monocytes from bone marrow target mononuclear cells. No inhibition of autologous marrow CFU-GM or CFU-GEMM was observed following co-culture with patient peripheral blood mononuclear cells.

A similar selective concentration-dependent inhibition of BFU-E colony growth was observed following co-culture of patient blood mononuclear cells or patient Leu $2+\mathrm{T}$ cells with two separate unrelated $\mathrm{T}$ cell-depleted allogeneic marrows. $\mathrm{Pa}$ tient mononuclear cells had no effect on allogeneic CFU-GM or CFU-GEMM colony formation. Control peripheral blood mononuclear cells or control Leu $2+$ peripheral blood $\mathrm{T}$ cells had no consistent effect on growth of allogeneic BFU-E.

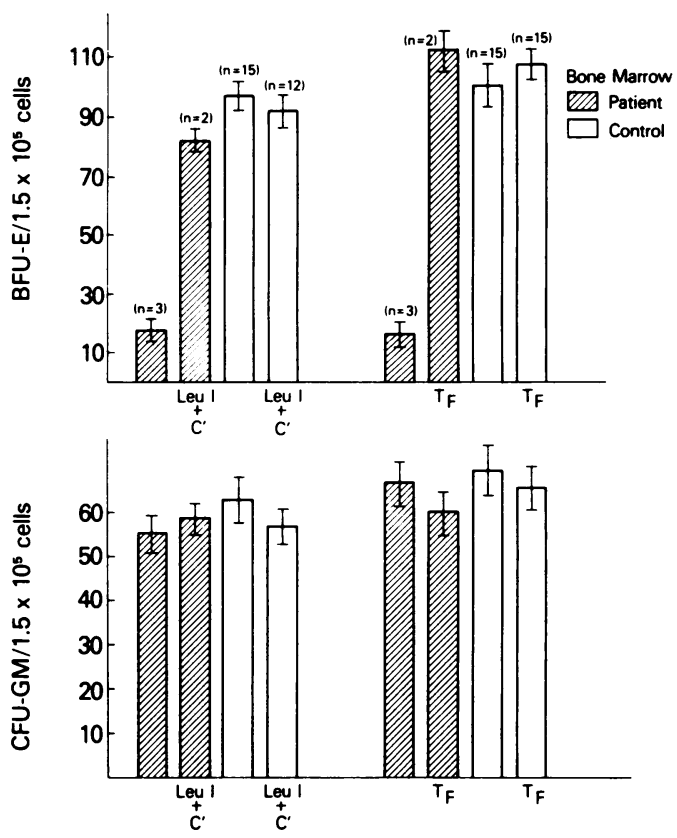

Figure 1. Growth of patient and control marrow early erythroid (BFU-E) and granulocyte-macrophage (CFU-GM) hematopoietic progenitors before and after marrow $\mathrm{T}$ cell depletion by either incubation with pan-T Leu 1 monoclonal antibody plus complement $\left(C^{\prime}\right)$ or by immunoabsorption ("panning") with Leu 1 monoclonal antibody $\left(T_{F}\right)$. Colony values post-depletion are corrected for progenitor enrichment based upon extent of marrow $\mathrm{T}$ cell removal. Results expressed as means $\pm \mathrm{SD}$.

Inhibition of in vitro BFU-E growth was also observed following co-culture of nonadherent autologous or allogeneic marrow with conditioned media (CM) derived from patient Leu $2+\mathrm{T}$ cells. Fig. $2 B$ indicates the effect of unstimulated 72-h CM, derived from either patient or control Leu $2+$ blood mononuclear cells, on growth of allogeneic BFU-E. Unstimu-
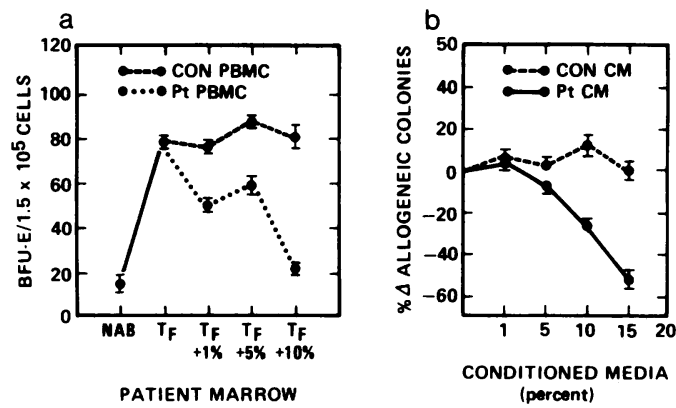

Figure 2. (A) Growth of patient marrow early erythroid (BFU-E) hematopoietic progenitors before and after the addition of $1-10 \%$ autologous or control Leu 2+ peripheral blood mononuclear cells (PBMC) to nonadherent $T$ cell-depleted $\left(T_{F}\right)$ patient marrow. Patient monocyte-depleted nonadherent buoyant (NAB) marrow mononuclear cells were either assayed directly for BFU-E or first depleted of $T$ cells $\left(T_{F}\right)$ by immunoabsorbent panning with Leu 1 pan-T-cell monoclonal antibody before co-culture with PBMC. Results expressed as means \pm SD from three separate experiments. $(B)$ Growth of allogeneic marrow early erythroid (BFU-E) hematopoietic progenitors following co-culture with $1-15 \%(v / v)$ conditioned media (CM) derived either from patient or control peripheral blood Leu $2+$ blood mononuclear cells (PBMC). Results expressed as means \pm SD from three separate experiments. 
lated and PHA-stimulated CM from patient peripheral blood cells produced comparable degrees of allogeneic BFU-E inhibition. No inhibition of allogeneic BFU-E was noted after coculture with unstimulated or stimulated CM from control Leu $2+$ peripheral blood T cells (Fig. 2 B). Patient Leu $2+\mathrm{CM}$ at comparable concentrations failed to inhibit allogeneic CFUGM. Gamma interferon activity $(950 \mathrm{U} / \mathrm{ml})$ was detected in 72-h conditioned media generated from patient unstimulated peripheral blood mononuclear cells; this level of activity is comparable to that found $(300-6,000 \mathrm{U} / \mathrm{ml})$ in conditioned media generated from control blood mononuclear cells after stimulation with $50-100 \mu \mathrm{g} / \mathrm{ml}$ of the $\mathrm{T}$ cell mitogen Con A (34). The soluble inhibitory factor derived from patient CM was sensitive to trypsin and was completely acid-labile (pH 2) and could be destroyed by incubation at $56^{\circ} \mathrm{C}$ for $1 \mathrm{~h}$.

Conditioned media prepared from Leu $2+$ patient peripheral blood mononuclear cells 2 mo after cessation of cyclophosphamide, and while in hematologic remission, no longer inhibited growth of autologous cryopreserved BFU-E. Conditioned media were also prepared, before beginning immunosuppressive therapy, from patient peripheral blood Leu $2+\mathrm{T}$ cells or from panned marrow $\mathrm{T}$ cells before and after cell incubation with anti-HLA-DR (2.06) monoclonal antibody plus complement. Media prepared from marrow $T$ lymphocytes depleted of HLA-DR-bearing T cells no longer inhibited cryopreserved autologous marrow BFU-E; CM prepared from marrow mononuclear cells pretreated with pan-T Leu 1 monoclonal antibody plus complement similarly no longer inhibited autologous BFU-E (data not shown).

Effect of Interleukin 2 on mitogen-induced proliferation of patient peripheral blood mononuclear cells. In vitro T cell proliferation assays using patient peripheral blood mononuclear cells and cells from three separate unrelated controls were next used to assess the basis for the patient's impaired cutaneous delayed hypersensitivity reactions. Patient cells responded poorly to each of two separate T cell mitogens (Fig. 3): patient proliferative response to PHA was $14 \%$ of control and patient response to Con A was only $5 \%$ of control. Response to the $\mathrm{T}$ cell-dependent B cell PWM was $72 \%$ of control.

Preparations enriched for the lymphokine interleukin 2 can obviate the requirement for $T$ cell help in in vitro systems and have been shown to augment animal in vivo immune responses (21). We thus examined the ability of interleukin 2 to restore mitogen-induced proliferation of patient mononuclear cells (Fig. 3). When interleukin 2-containing conditioned medium was added to patient peripheral blood mononuclear cells, mitogen-induced proliferative responses were increased 16-fold with PHA and 21-fold with Con A, whereas no augmentation was found in control PHA proliferative responses, and only a 2-fold increment was found in control Con A response. Similar increments in patient PHA and Con A proliferative responses were seen utilizing either purified recombinant interleukin 2 or interleukin 2-medium derived from the supernatants of mitogen-stimulated lymphocytes. Stimulated supernatants derived from cultures of patient peripheral blood mononuclear cells did not support proliferation of cultured interleukin 2-dependent mouse $\mathrm{T}$ cells.

HTLV serologies and molecular hybridization studies. Viral infections have been associated in humans with the development of aplastic anemia, transient arrest of erythropoiesis, acquired immune deficiencies, lymphoproliferative disorders and, rarely, with chronic red cell aplasia $(2,4,35,36)$. Patient serum specimens were thus tested, shortly after diagnosis, for antigens to, or antibody to: cytomegalovirus (CMV) by complement fixation and indirect hemagglutination; hepatitis B virus (HBV) by hepatitis B surface antigen and antibody to hepatitis $B$ core antigen; and Epstein-Barr virus (EBV) by IgG and IgM antibodies to viral capsid antigen, and antibodies to nuclear antigen and early antigens. No serological evidence was found for recent or persistent infection with $\mathrm{CMV}, \mathrm{HBV}$, or EBV. Patient urine and throat cultures were negative for CMV and herpes simplex virus types 1 and 2 .

Patient serum was next assessed for the presence of antibodies to human $T$ cell leukemia virus membrane antigens (HTLV-MA). Utilizing indirect immunofluorescence and flow cytometric analysis, patient serum reacted with $>90 \%$ of cells from each of two separate HTLV-infected cell lines (Hut 102 and MT 2) but failed to react $(<10 \%)$ with control human B or $\mathrm{T}$ lymphoid lines. Patient serum was also assessed by radioimmunoprecipitation with $\left[{ }^{35} \mathrm{~S}\right]$ methionine-labeled Hut 102 cells: the serum sample showed clear precipitation of glycoprotein antigen 61 (p61), a 61,000-D glycoprotein frequently

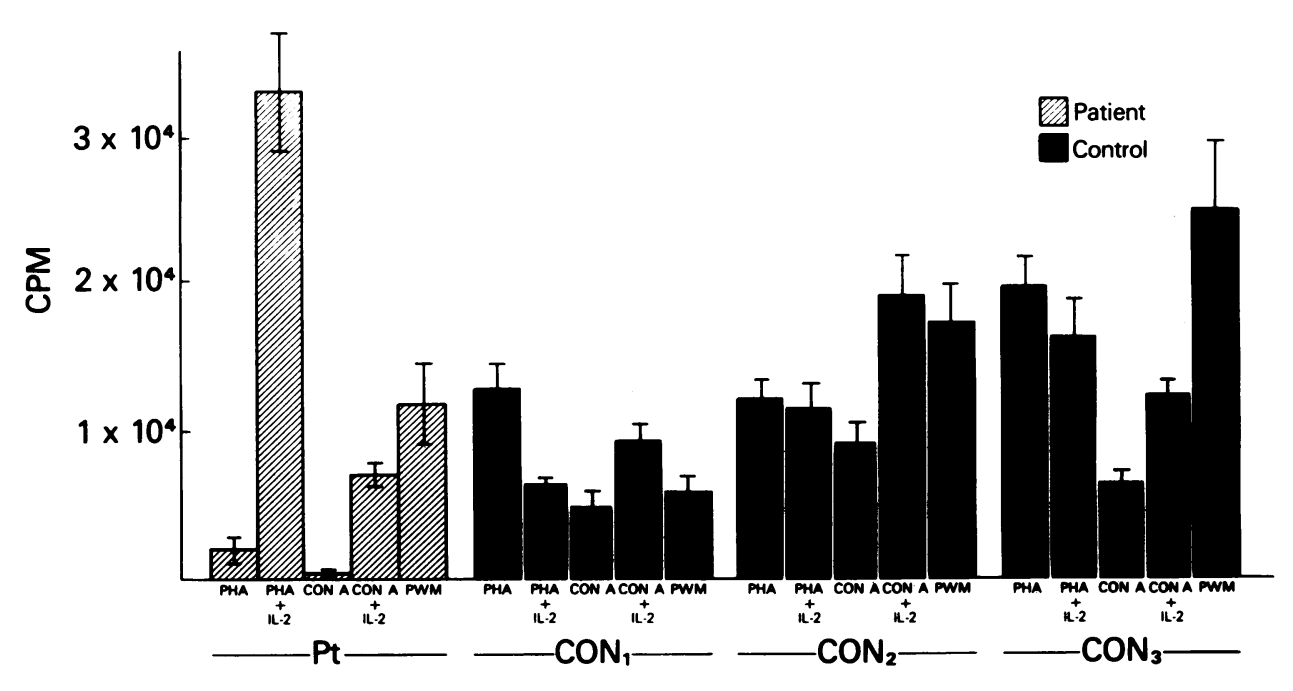

Figure 3. Mitogenic proliferation of peripheral blood mononuclear cells (PBMC) from patient $(\mathrm{Pt})$ and three separate controls $\left(\mathrm{CON}_{1}, \mathrm{CON}_{2}\right.$, $\mathrm{CON}_{3}$ ) in the absence and in the presence of $10 \%$ interleukin 2 (IL 2)-containing conditioned medium. Following addition of IL 2, Pt PBMC proliferative responses were increased 16-fold with phytohemagglutinin (PHA) and 21 -fold with concanavalin $\mathrm{A}$ (Con $\mathrm{A}$ ), whereas no augmentation was found in control PHA responses, and only a 2fold increment was found in control Con A responses. Results expressed as mean counts per minute (cpm) \pm SEM from two separate experiments, PWM, pokeweed mitogen. 
detected by human antibodies from HTLV-I-infected Japanese T cell leukemia patients (23). No precipitation of p61 was observed when patient serum was reacted with 8402 , an HTLV-uninfected human $T$ cell line. Two separate patient serum samples, obtained three months apart, showed similar degrees of reactivity when tested for HTLV-MA antibodies. The first serum sample was obtained after the patient had received a total of seven units of packed red blood cells after the diagnosis of red cell aplasia; none of these seven donors belonged to groups known to be at increased risk for carriage of HTLV and all seven donors had normal (1.60-2.15) peripheral blood $T_{H} / T_{S}$ ratios. No information was available with regard to the three individuals who donated packed red blood cells to the patient 18 mo before the diagnosis of red cell aplasia.

Patient serum was independently assessed for antibodies to HTLV-I, II, and HIV by Western blot assays (Fig. 4). Serum from the patient reacted with HTLV-I antigens (p19 and p24) and with HTLV-II p24 antigen; patient serum reacted in trace amounts or not at all with HIV antigens (p18, p24, p41, p55, p65). This pattern of reactivity is characteristic of HTLV-I immune sera (37).

Patient fresh and cultured peripheral blood mononuclear cells, obtained before immunosuppressive therapy, were assessed for presence of HTLV core antigens in an indirect immunofluorescence cytofluorographic assay (Table I). Greater than $95 \%$ of patient mononuclear cells bore pan-T Leu 4 and suppressor-cytotoxic Leu 2 surface determinants at the time of cytofluorographic analysis. 1-2\% of patient fresh cells and $7-11 \%$ of cultured cells showed the presence of antigens reactive with antibody to HTLV core proteins p19 and p24. Patient cultured mononuclear cell immunofluorescence was

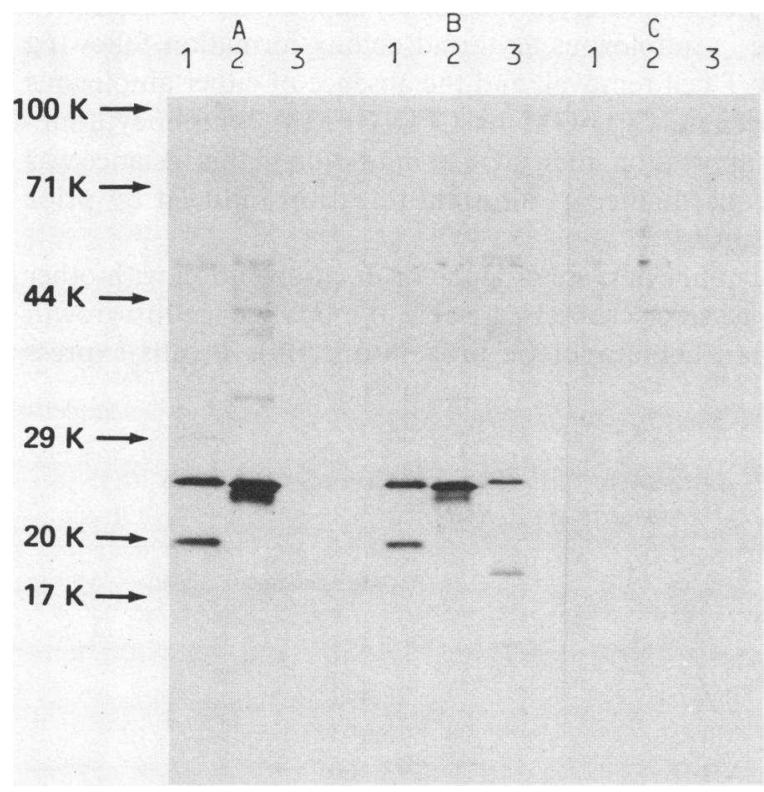

Figure 4. Western blot analysis of antibodies to HTLV-I (lane 1), HTLV-II (lane 2) and HIV (lane 3). Banding patterns of patient serum $(A)$ were compared with those of a known positive $(B)$ serum control containing a mixture of antisera reactive with HTLV-I, II, and HIV antigens, and with a nonimmune $(C)$ serum control. $\mathrm{Pa}$ tient serum reacted with HTLV-I core antigens (p19 and p24), with HTLV-II p24 antigen, but trace or not at all with HIV antigens.
Table I. Assessment of HTLV-I Core Proteins p19 and p24 in Patient Fresh and Cultured Peripheral Blood

Mononuclear Cells (MNC)

\begin{tabular}{|c|c|c|c|c|}
\hline & \multicolumn{4}{|c|}{$\%$ Cells positive by IF } \\
\hline & \multirow[b]{2}{*}{ p19 } & \multirow[b]{2}{*}{ p24 } & \multicolumn{2}{|c|}{ Control antisera } \\
\hline & & & Mouse & Goat \\
\hline Patient fresh MNC $(n=2)$ & $2 \pm 1^{*}$ & $1 \pm 0.5$ & 0 & 0 \\
\hline Patient cultured MNC $(n=2)$ & $11 \pm 3$ & $7 \pm 2$ & 0 & 0 \\
\hline $\begin{array}{l}\text { Control fresh Leu } 2+\text { MNC } \\
(n=5)\end{array}$ & 0 & 0 & ND & ND \\
\hline $\begin{array}{l}\text { Control cultured Leu } 2+\mathrm{MNC} \\
\quad(n=2)\end{array}$ & 0 & 0 & ND & ND \\
\hline Cultured interleukin- 2 depende & & & & \\
\hline Leu $2+\mathrm{T}$ cell clone $(n=2)$ & 0 & 0 & ND & ND \\
\hline
\end{tabular}

Cultured cells were assessed by immunofluorescence (IF) and flow cytometry after 7 and $21 \mathrm{~d}$ of incubation. ND, not done.

* Mean \pm SD from two to five separate experiments.

abrogated by first incubating the HTLV core protein antisera with extracts of HTLV-I producing (Hut 102) cells but not by prior incubation of antisera with PHA-stimulated control lymphocyte extracts. Two-color flow cytometry of patient cultured mononuclear cells demonstrated co-expression of the p19 core antigen with either the Leu 2 or the Leu 7 surface determinant. Patient cells were not reactive with control mouse and goat antisera. Control fresh and cultured Leu 2+ Leu 7+ mononuclear cells, as well as cultured Leu 2+ Leu 7+ cloned $T$ cells, were not reactive with the HTLV core protein antisera (Table I). Patient cells were again evaluated for HTLV core antigens by immunofluorescence 5 mo after cessation of immunosuppressive therapy: cultured cells $(5-9 \%)$ but not fresh cells continued to demonstrate antigens reactive with antibody against p19 and p24 core proteins.

Patient peripheral blood mononuclear cells were established in culture $5 \mathrm{mo}$ after cessation of immunosuppressive therapy. Cultured patient cells and two control $\mathrm{T}$ cell lines were analyzed for the presence and expression of HTLV-I genomic sequences by RNA dot blot, utilizing a ${ }^{32} \mathrm{P}$-nick translated DNA probe derived from the envelope region of a HTLV-I molecular clone (Fig. 5). Patient cells (lane 3) expressed HTLV-I specific RNA at levels nearly comparable to that of an HTLV-I infected (MT-2) (38) control cell line (lane 1). An uninfected T cell line (lane 2) failed to express HTLV-I specific RNA sequences. DNA derived from cultured patient cells was cleaved with either Eco RI or Bam HI and transferred to nitrocellulose for hybridization with a HTLV-I specific ( $\mathrm{pX}$

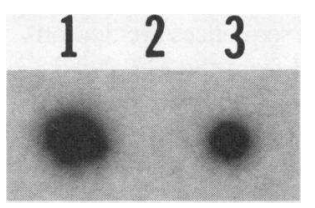

Figure 5. RNA dot blot performed utilizing a ${ }^{32} \mathrm{P}$-nick translated DNA probe derived from the envelope region of an HTLV-I molecular clone. Cells from a known HTLV-I-producing line (MT-2) (lane 1), an uninfected (H9) $\mathrm{T}$ cell line (lane 2) and patient cells (lane 3) were prepared and dot blotted to assess for the expression of HTLV-I genomic sequences. Patient cells expressed HTLV-I specific RNA at levels nearly comparable to that of the positive control (MT-2) cell line. 
region) probe (Fig. $6 \mathrm{~A}$ ). The presence of clonal integrated HTLV-I sequences was demonstrated in patient DNA (lane 3) and in DNA derived from a known HTLV-I producer (MT-2) cell line (lane 4). No integrated HTLV-1 genomic sequences were demonstrable in DNA derived from a B cell lymphoblastoid (LB2) cell line (lane 1) or in DNA from an uninfected (Jurkatt) T cell line (lane 2). Genomic blot hybridizations were also performed with patient and control cell-derived DNA using a probe for the beta chain of the T cell receptor (Fig. $6 B$ ). In contrast to a control B cell line (lane 1) or a noninfected T cell line (lane 2), patient DNA demonstrated a non-germ-line configuration (lane 3), providing presumptive evidence for $\mathrm{T}$ cell beta chain gene rearrangement and for clonality.

Concentrated supernatants from patient and control cell
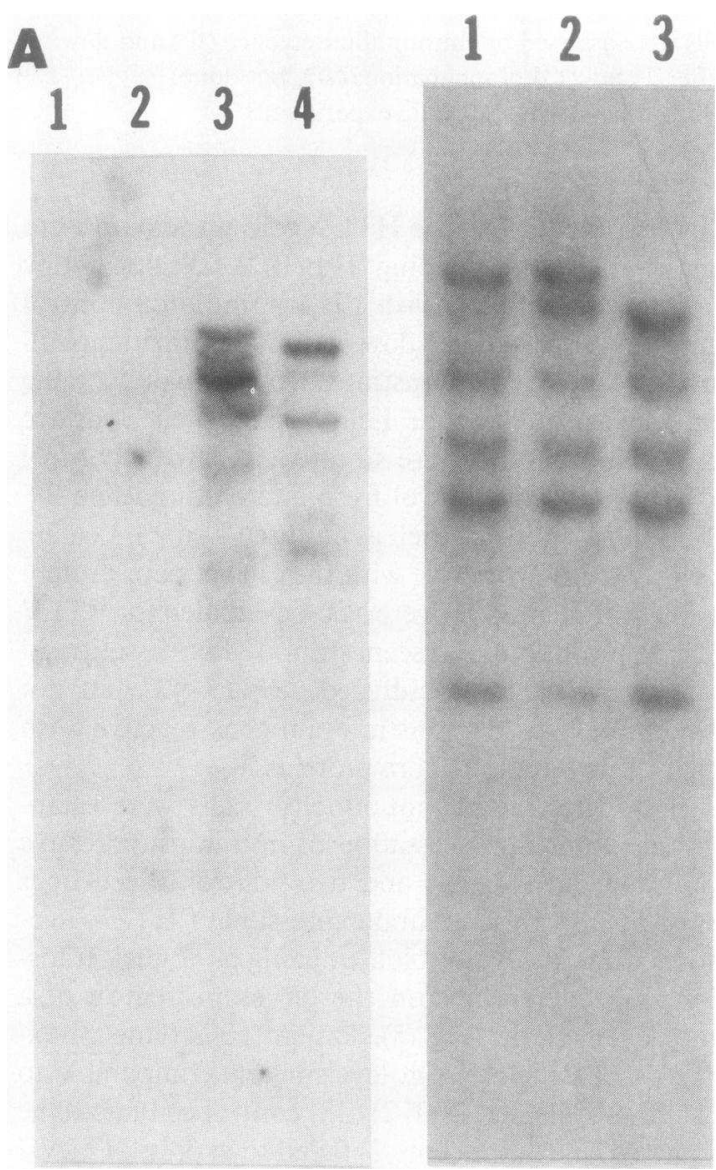

Figure 6. (A) Southern blot performed utilizing a HTLV-I specific (pX region) probe to assess patient and control DNA for the presence of clonal integrated HTLV-I genomic sequences. (Lane 1 ) B cell lymphoblastoid (LB2) cell line; (lane 2) control uninfected (Jurkatt) cell line; (lane 3) patient cells; (lane 4) known HTLV-I producing (MT-2) T cell line. Clonal integrated HTLV-I sequences are demonstrated in DNA derived from patient cells and from the MT- 2 cell line. The different blot sequences in lanes 3 and 4 indicate probable separate sites of genomic integration in patient cells and the MT-2 cell line. $(B)$ Southern blots were performed on patient and control cell-derived DNA using a probe for the T cell receptor $\beta$-chain to look for possible $T$ cell receptor gene rearrangements. In contrast to the B cell lymphoblastoid (LB2) cell line (lane 1) and a noninfected (Jurkatt) $\mathrm{T}$ cell line (lane 2), DNA derived from cultured patient cells (lane 3) demonstrates a clonal non-germ-line configuration. cultures were assayed for viral reverse transcriptase activity (Table II). Enzyme activity was demonstrable in the supernatant derived from cultured patient cells. Comparable activity was seen in supernatant derived from a control (MT-2) HTLV-I infected T cell line. Examination of cultured patient cells by thin-section electron microscopy (Fig. 7) revealed particles typical of type $C$ retrovirus. Viral particles (arrows) were ovoid in shape, $\sim 90 \mathrm{~nm}$ in diameter and were surrounded by a double-layered membrane that had the appearance and dimensions of the outer membrane of the cultured cells. The viral particle centers contained an electron opaque core with a narrow translucent rim between it and the outer membrane (Fig. 7, inset). Occasional particles had a less well-defined center and a single short, thin rod-like protrusion extending from their surface.

\section{Discussion}

We have described a patient with chronic large granular lymphocytosis, anergy, hypogammaglobulinemia, and T suppressor cell inhibition of erythropoiesis, associated with markers of infection for type I HTLV. T cell depletion of patient marrow by either antibody and complement-mediated cytolysis, or by "panning" produced a selective increase in autologous erythroid (BFU-E) progenitors. Patient T cells in co-culture were capable of selective inhibition of both autologous and allogeneic marrow erythropoiesis. This inhibition appeared to be mediated via a soluble product secreted by an expanded population of autologous activated (HLA-DR+) suppressor T lymphocytes bearing anomalous (Leu 11) surface antigenic determinants. Patient $T$ cell suppression of erythroid colony growth could no longer be demonstrated following resolution of the marrow red cell aplasia and a concomitant increase in the peripheral blood $T_{H} / T_{S}$ immunophenotypic ratio. The presence of autologous erythroid colony suppression, the selective increase in autologous erythroid colony formation following marrow $\mathrm{T}$ cell removal, and the absence of either autologous or allogeneic CFU-GM or CFU-GEMM lymphocyte-mediated suppression, indicate that inhibition in this instance was not a consequence of alloimmunization induced by prior transfusions.

T lymphocytes, either alone or in co-operation with other mononuclear cell subsets, are able to modulate in vitro growth of human hematopoietic progenitors (39). T cells express

Table II. Assessment of Patient and Control Cell Lines for Reverse Transcriptase Activity

\begin{tabular}{lc}
\hline Cell line & Reverse transcriptase activity \\
\hline & $c p m$ \\
Patient & $23,442^{*}$ \\
MT-2 & 15,903 \\
VB & 193,460 \\
Blank & 780
\end{tabular}

Spent supernatants from indicated cultures were pelleted at 100,000 $g$ for $90 \mathrm{~min}$ at $4^{\circ} \mathrm{C}$ and assayed for enzyme activity according to published methods (33). MT-2 is a HTLV-I producing positive control cell line (38) and VB is a HIV-producing cell line (67).

* Mean from two separate experiments. 


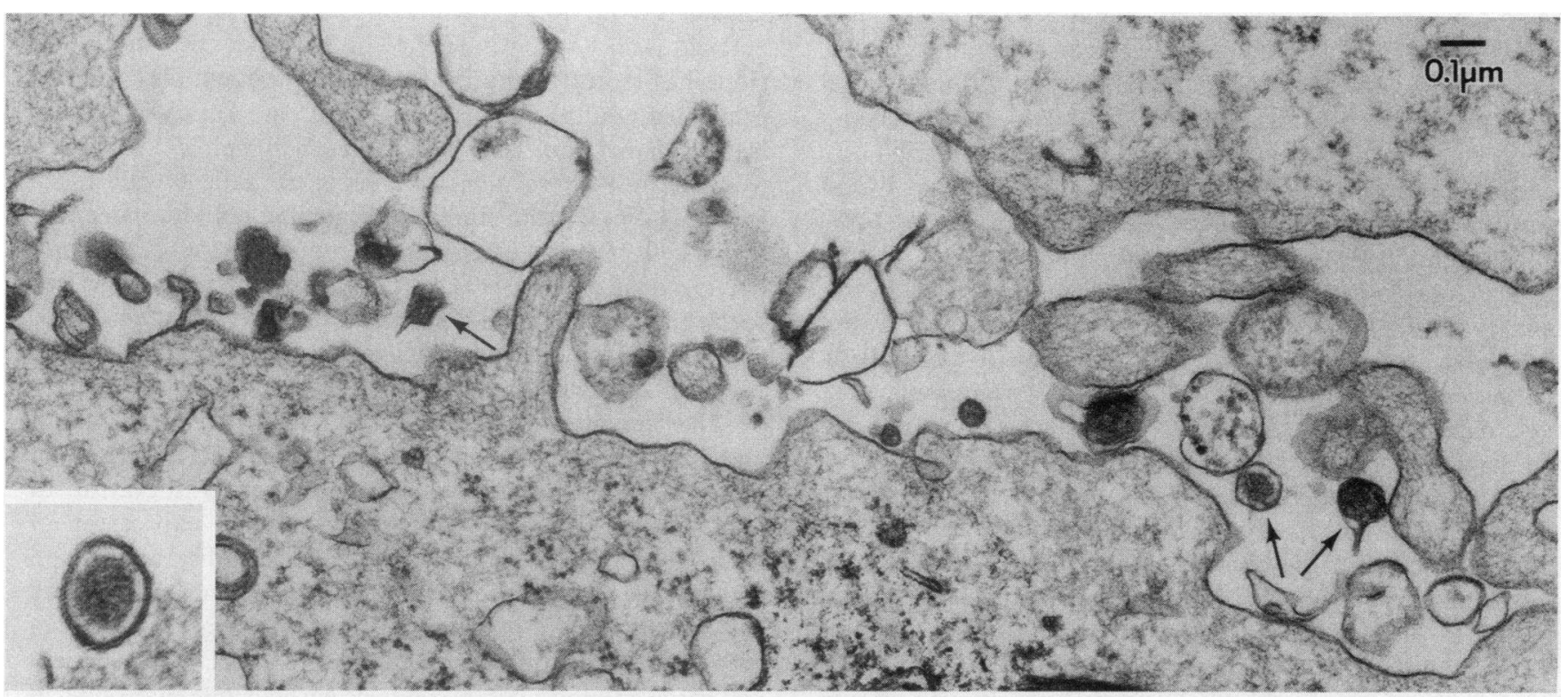

Figure 7. (51,000 magnification) Thin-section electron microscopy was performed on cultured patient cells. Demonstrated among the cytoplasmic processes and debris between two closely juxtaposed cells are a number of ovoid viral particles (arrows). The insert in the left lower corner (130,000 magnification) shows a typical cross-sectioned virus $\sim 90 \mathrm{~nm}$ in diameter with an electron opaque core and narrow translucent rim between it and the outer double-layered membrane.
HLA-DR determinants upon cell activation in vitro and HLA-DR-bearing $T$ cells are present in vivo under conditions that lead to $T$ cell activation (40). Ia-like (HLA-DR+) normal human T cells are also capable of limiting BFU-E growth (41). In our patient, conditioned media prepared either from peripheral blood or marrow $T$ cells, selectively depleted of HLADR-bearing $T$ cells by prior treatment with anti-HLA-DR monoclonal antibody plus complement, no longer inhibited allogeneic or autologous marrow BFU-E. The exact mechanism of $T$ suppression of erythropoiesis in this instance is not clear. Torok-Storb's observations suggest that HLA-DR+ normal human $\mathrm{T}$ cells may prevent in situ elaboration of an erythropoietic stimulating activity by interfering with $\mathrm{T}$ cell-monocyte collaboration (41). T cells from our patient, however, produced autologous suppression of BFU-E from marrow target cells depleted of both monocytes and T cells. Autologous T cell-mediated suppression of BFU-E also occurred both in the presence and absence of a known source (Mo CM) of burstpromoting activity (10), suggesting that inhibition in this instance was not mediated via a direct effect on an accessory BPA-producing cell.

Patient $\mathrm{T}$ cell-conditioned media suppression of both autologous and allogeneic BFU-E suggests that erythrocyte inhibition in this patient was mediated by a soluble T-lymphokine and was not genetically restricted (HLA-DR restriction of erythrocyte suppression has been reported recently in a patient with lymphocytosis and red cell aplasia [8]). Gamma interferon activity was detected in conditioned media generated from our patient's unstimulated peripheral blood mononuclear cells and may have played a role in the ability of that media to inhibit in vitro erythropoiesis. The inhibitory activity of patient conditioned media was acid labile ( $\mathrm{pH} 2$ ), sensitive to trypsin, and was inactivated by incubation at $56^{\circ} \mathrm{C}$ for $1 \mathrm{~h}$, properties consistent with those of gamma interferon (42). Gamma interferon ( $\gamma$ INF) is a soluble lymphokine, produced by helper and suppressor $T$ cells, that appears to play a pivotal role in regulation of cellular immune responses $(34,43)$. Preparations of human $\gamma$ INF are capable of suppressing marrow hematopoietic progenitor formation in vitro (44). Recent observations suggest that erythroid colonies may be more sensitive to the suppressive effects of $\gamma$ INF than are granulocytemacrophage progenitors $(44,45)$, and that triggering of the $T$ cell antigen receptor complex (i.e., at the time of $T$ cell activation) obviates the requirement of antigen-presenting monocytes for optimal $\gamma$ INF-induced inhibition of BFU-E (46). Other studies indicate that activated (HLA-DR+) suppressor (Leu $2+$ ) lymphocytes producing $\gamma$ INF may have a role in the pathogenesis of bone marrow failure in patients with severe aplastic anemia (47). Spontaneous $\gamma$ INF production has also been observed from adult bone marrow $\mathrm{T}$ cells transformed by HTLV-I (48).

Impaired intradermal delayed hypersensitivity in this patient was associated with an inability of patient $\mathrm{T}$ cells to proliferate in vitro in response to either PHA or Con A. Although the patient had a profound deficit of helper-inducer Leu 3+ T cells and his peripheral blood cells appeared unable to produce interleukin 2, patient mononuclear cells were capable of responding to interleukin 2 in vitro with a marked augmentation, relative to control, in mitogen-induced proliferation. The helper lymphokine interleukin 2 can obviate the requirement for $\mathrm{T}$ cell help in several in vitro systems, and has been shown to enhance deficient in vitro immune responses in patients with acquired immunodeficiency and coexistent depletion of the helper inducer peripheral blood $\mathrm{T}$ lymphocyte subset (21).

The term "chronic T cell lymphocytosis" or "T $\gamma$-lymphoproliferative disease" has been utilized to encompass a recently described group of older, predominantly male, patients with a modest peripheral blood and marrow lymphocytosis, an absence of prominent lymphadenopathy or hepatomegaly, and a relatively indolent clinical course (6-9). Cells from these pa- 
tients have the morphologic characteristics of large granular lymphocytes (LGL). They regularly bear sheep erythrocyte (Leu 5) and suppressor (Leu 2) surface determinants and commonly express HLA-DR and NK cell-associated antigens. The precise lineage ( $T$ vs. NK vs. macrophage) of the LGL remains controversial, and it has been suggested that LGLs constitute a separate cell lineage sharing a common multipotent progenitor with both $\mathrm{T}$ cells and monocyte-macrophages $(6,9)$. Unexplained neutropenia has been seen in some patients with $\mathrm{T} \boldsymbol{\gamma}$-lymphoproliferative disease and at least two cases have been described with red cell aplasia (6-8). Many of our patient's clinical features, cell membrane immunophenotypic data and cellular functional studies are consonant with the diagnosis of the "chronic $\mathrm{T} \gamma$-lymphoproliferative disease (T $\gamma$-LPD)" syndrome. Some investigators have suggested that the immune phenotype and anomalous surface determinants expressed on cells from chronic T $\boldsymbol{\gamma}$-LPD patients represent a polyclonal expansion of a naturally occurring LGL subset present in normal individuals rather than a true neoplastic transformation with subsequent proliferation of a malignant clone $(8,49)$. Genomic blot hybridizations performed on our patient's cells using a probe for the $T$ cell receptor beta chain demonstrated a non-germ line configuration. Similar molecular biologic analyses performed in a small number of patients with $\mathrm{T} \gamma$-LPD suggest that the disorder is heterogeneous, although the majority of patients demonstrate clonal rearrangements of the $T_{\beta}$ gene, providing presumptive evidence for clonal $\mathrm{T}$ cell proliferation $(50,51)$.

The etiology of the chronic T $\boldsymbol{\gamma}$-LPD syndrome and its associated immunoregulatory abnormalities is uncertain. EBV has been associated with polyclonal and monoclonal lymphoproliferative disorders and, rarely, with red cell aplasia (36); both hepatitis B virus (HBV) and non-A, non-B hepatitis have been associated with the development of bone marrow failure (35). However, our patient had no demonstrable clinical or serological evidence to suggest hepatitis or recent infection with EBV, HBV, or cytomegalovirus. He did possess, however, high-titered antibodies to cell membrane antigens associated with the human T-cell leukemia virus (HTLV-MA) and a pattern of reactivity on Western blot analysis characteristic of HTLV-I immune sera $(37,52)$. Additionally, patient cultured Leu 2+ mononuclear cells expressed HTLV-I specific RNA and demonstrated clonal integrated HTLV-I DNA sequences. Further, particles typical of type $C$ retrovirus were identified by electron microscopy in cultured patient cells. Fresh and particularly cultured patient peripheral blood mononuclear cells showed staining with antibodies to HTLV-I core proteins p19 and p24. Expression of HTLV-I core proteins has been described in patients with adult $\mathrm{T}$ cell leukemia or lymphoma, and in a small number of patients with variant cutaneous $T$ cell lymphomas $(2,26)$. Type $C$ retrovirus-like particles and HTLV-I core proteins have also recently been detected in fresh as well as cultured blood cells from at least two hemophiliacs with AIDS (53).

Cytofluorographic analysis of patient mononuclear cells demonstrated coexpression of the p19 core antigen with the suppressor-cytotoxic (Leu 2) determinant and cultured patient Leu $2+$ cells contained clonal integrated HTLV-I DNA sequences. Although HTLV is usually considered tropic for helper-inducer $\mathrm{T}$ lymphocytes, recent studies indicate that HTLV-I is clearly capable of transforming adult bone marrow suppressor-cytotoxic $T$ cells $(48,54)$. These HTLV-trans- formed T lymphocytes bear Leu 2 as well as Leu 7 surface determinants (48). An HTLV-transformed B lymphocyte clone has recently been isolated from a patient with HTLVassociated adult T cell leukemia (55), and HTLV-I has also been isolated from Leu $2+$ mature $\mathrm{T}$ lymphocytes derived from the healthy relatives of a Japanese patient with $T$ cell leukemia (56). Recent studies indicate that both human endothelial cells (57) and osteogenic sarcoma cells (58) can be productively infected by HTLV-I, suggesting that the target cell spectrum of this virus is not limited strictly to lymphoid cells. Adult $\mathrm{T}$ cell leukemia involving a suppressor cell phenotype has been reported but is very rare (59).

The presence in serum of HTLV-MA, p19, and p24 antibodies, the expression of p19 and p24 HTLV core antigens on patient mononuclear cells, as well as the integration of HTLV-I proviral DNA sequences and the expression of HTLV-I genomic sequences in patient cells indicates infection with HTLV-I and raises the possibility of an etiologic link between human retrovirus infection and some instances of large granular lymphocytic leukemia (T $\gamma$-LPD). Our patient had received blood components as early as one and one-half years prior to documentation of his lymphocytosis and red cell aplasia, but did not otherwise belong to any group with an increased incidence of AIDS or HTLV exposure. Recent reports indicate that HTLV-I can be transmitted through transfusion of blood components from single donors (60). The precise explanation for the development of red cell aplasia in this patient with HTLV-associated T $\gamma$-LPD is not clear, but may be related to either the specific site of viral genomic integration or the unusual host target cell for the virus (48). T cell suppression of autologous marrow granulopoietic progenitors has been reported in a small number of AIDS patients (61). Infection in cats with an analogous $\mathrm{T}$ cell-tropic retrovirus, feline leukemia virus (FLV), can also cause a $\mathrm{T}$ cell leukemia as well as immunosuppression and either marrow or lymphoid hypoplasia (62). In some cats FLV induces a rapidly developing erythroid aplasia (62). Other RNA tumor retroviruses have been shown to alter the growth potential of erythroid progenitors without interfering with the ability of these cells to differentiate (63).

Seroepidemiologic studies indicate that HTLV-I is endemic not only in areas of the Orient and the Caribbean basin but can also be found in a variety of locations in the United States, Britain, and the European continent $(60,64)$. Very recently a bisexual patient with clinical manifestations of AIDS-related complex and a Leu 2+ lymphocytosis has been described (65). This patient was infected with both HTLV-I and HIV; evidence was provided, however, that the Leu 2+ cell proliferation was a direct consequence of HTLV-I infection. A single case has been reported of a Sicilian woman with leukopenic chronic $\mathrm{T}$ cell leukemia and serologic evidence of infection with HTLV-I by Western blot (66). Many of the leukemic cells from this patient had the morphologic appearance of large granular lymphocytes. Immunologic studies demonstrated that the predominant lymphoid cell population from this patient expressed T8 (Leu 2) surface determinants. No further studies were performed, however, to demonstrate integrated HTLV-I genomic sequences or expression of HTLV-I specific RNA transcripts.

Our results in combination with the above reports expand the spectrum of HTLV-associated lymphoproliferative disease and suggest that further studies are warranted to determine 
what role HTLV-I may play in the development of selected bone marrow failure states and the chronic T $\gamma$-LPD syndrome.

\section{Acknowledgments}

We would like to thank Dr. C. Cabradilla for performance of the initial HTLV-MA immunofluorescence assay and Dr. J. Steven McDougal for performance of the Western blot assays. Sera for HTLV immunofluorescence tests and the HTLV-I genomic probes were obtained through the courtesy of Dr. Robert Gallo of the National Cancer Institute in Bethesda, MD. We gratefully acknowledge the excellent technical assistance of Lorela Fajardo and Diana Thompson and the expertise of Janet Scrimger in the preparation of this manuscript.

Supported in part by funds from the Giannini Foundation and the National Institutes of Health (1 R01 HL-35774).

\section{References}

1. Poiesz, B. J., F. W. Ruscetti, A. F. Gazdar, P. A. Bunn, J. D. Minna, and R. C. Gallo. 1980. Detection and isolation of type C retrovirus particles from fresh and cultured lymphocytes of a patient with cutaneous T-cell lymphoma. Proc. Natl. Acad. Sci. USA. 77:7415-7419.

2. Blayney, D. W., E. S. Jaffe, W. A. Blattner, J. Cossman, M. Robert-Guroff, D. L. Longo, P. A. Bunn, and R. C. Gallo. 1983. The human T-cell leukemia/lymphoma virus associated with american adult T-cell leukemia/lymphoma. Blood. 62:401-405.

3. Bunn, P. A., G. P. Schechter, E. S. Jaffe, D. Blayney, R. C. Young, M. J. Matthews, W. Blattner, S. Broder, M. Robert-Guroff, and R. C. Gallo. 1983. Clinical course of retrovirus-associated adult T-cell lymphoma in the United States. N. Engl. J. Med. 309:257-264.

4. Broder, S., and R. C. Gallo. 1984. A pathogenic retrovirus (HTLV-III) linked to AIDS. N. Engl. J. Med. 311:1292-1297.

5. Gallo, R. C. 1984. Human T-cell leukaemia-lymphoma virus and T-cell malignancies in adults. Cancer Survey. 3:113-159.

6. Reynolds, C. W., and K. A. Foon. 1984. T $\gamma$-lymphoproliferative disease and related disorders in humans and experimental animals: $\mathrm{A}$ review of the clinical, cellular, and functional characteristics. Blood. 64:1146-1158.

7. Newland, A. C., D. Catovsky, D. C. Linch, J. C. Cawley, P. Beverley, J. F. San Miguel, E. C. Gordon-Smith, T. E. Blecher, S. Shahriari, and S. Varadi. 1984. Chronic T cell lymphocytosis. Br. J. Haematol. 58:433-446.

8. Lipton, J. M., L. M. Nadler, G. P. Canellos, M. Kudisch, C. S. Reiss, and D. G. Nathan. 1983. Evidence for genetic restriction in the suppression of erythropoiesis by a unique subset of $\mathrm{T}$ lymphocytes in man. J. Clin. Invest. 72:694-706.

9. Chan, W. C., I. Check, C. Schick, R. K. Brynes, J. Kateley, and E. F. Winton. 1984. A morphologic and immunologic study of the large granular lymphocyte in neutropenia with $\mathrm{T}$ lymphocytosis. Blood. 63:1133-1140.

10. Golde, D. W., N. Bersch, S. G. Quan, and A. J. Lusis. 1980. Production of erythroid-potentiating activity by a human T-lymphoblast cell line. Proc. Natl. Acad. Sci. USA. 77:593-596.

11. Levitt, L. J., C. A. Ries, and P. L. Greenberg. 1983. Pure white cell aplasia: antibody-mediated autoimmune inhibition of granulopoiesis. N. Engl. J. Med. 308:1141-1146.

12. Levitt, L. J., T. J. Kipps, E. G. Engleman, and P. L. Greenberg. 1985. Human bone marrow and peripheral blood $T$ lymphocyte depletion: efficacy and effects of both T-cells and monocytes on growth of hemotopoietic progenitors. Blood. 65:663-679.

13. Charron, D. J., and H. O. McDevitt. 1979. Analysis of HLA-D region-associated molecules with monoclonal antibody. Proc. Natl. Acad. Sci. USA. 76:6567-6571.
14. Howard, F. D., J. A. Ledbetter, J. Wond, C. P. Bieber, E. B. Stinson, and L. A. Herzenberg. 1981. A human T lymphocyte differentiation marker defined by monoclonal antibodies that block E-rosette formation. J. Immunol. 126:2117-2122.

15. Lanier, L. L., A. M. Le, J. H. Phillips, N. L. Warner, and G. F. Babcock. 1983. Subpopulations of human natural killer cells defined by expression of the Leu 7 (HNK-1) and Leu 11 (NK-15) antigens. $J$. Immunol. 131:1789-1796.

16. Dimitriu-Bana, A., G. R. Burmester, S. J. Waters, and R. J. Winchester. 1983. Human mononuclear phagocyte differentiated antigens. J. Immunol. 130:145-152.

17. Damle, N. K., N. Mohagheghpour, J. A. Hansen, and E. G. Engleman. 1983. Alloantigen-specific cytotoxic and suppressor $\mathrm{T}$ lymphocytes are derived from phenotypically distinct precursors. $J$. Immunol. 131:2296-2300.

18. Meeker, T. C., R. Miller, M. Link, J. Bindl, R. Warnke, and R. Levy. 1984. A novel human B lymphocyte antigen defined by a monoclonal antibody. Hybridoma. 3:305-320.

19. Greenberg, P., S. Baker, M. Link, and J. Minowada. 1985. Immunologic selection of human hematopoietic precursor cells. Blood. 65:190-197.

20. Levitt, L. J., G. Kansas, S. Foung, and E. Engleman. 1984. Effects of purified immunoregulatory T-cell subsets on human erythropoiesis. Blood. 64(Suppl. 1):115a. (Abstr.).

21. Lifson, J. D., D. F. Mark, C. J. Benike, K. Koths, and E. G. Engleman. 1984. Human recombinant interleukin-2 partly reconstitutes deficient in-vitro immune responses of lymphocytes from patients with AIDS. Lancet. i:698-702.

22. Rubin, B. Y., A. H. Bartal, S. L. Anderson, S. K. Millet, Y. Hirshaut, and C. Feit. 1983. The anticellular and protein-inducing activities of human $\gamma$-interferon preparations are mediated by the interferon. J. Immunol. 130:1019-1021.

23. Essex, M., M. F. McLane, T. H. Lee, N. Tachibana, J. Mullins, J. Kreiss, C. K. Kasper, M.-C. Poon, A. Landay, S. F. Stein, D. P. Francis, C. Cabradilla, D. Lawrence, and B. Evatt. 1983. Antibodies to human T-cell leukemia virus membrane antigens (HTLV-MA) in hemophiliacs. Science (Wash. DC). 221:1061-1064.

24. Tsang, V. C., J. M. Peralta, and A. R. Simons. 1983. Enzymelinked immunoelectrotransfer blot techniques (EITB) for studying the specificities of antigens and antibodies separated by gel electrophoresis. Methods Enzymol. 92:377-391.

25. Robert-Guroff, M., V. S. Kalyanaraman, and M. G. Sarngadharan. 1980. Radioimmunoassay for infectious primate retrovirus reverse transcriptase. Int. J. Cancer. 25:749-756.

26. Robert-Guroff, M., F. W. Ruscetti, L. E. Posner, B. J. Poiesz, and R. C. Gallo. 1981. Detection of the human T cell lymphoma virus p19 in cells of some patients with cutaneous $T$ cell lymphoma and leukemia using a monoclonal antibody. J. Exp. Med. 154:1957-1964.

27. Sabatini, D. D., K. G. Bensch, and R. J. Barrnett. 1963. Cytochemistry and electron microscopy. J. Cell Biol. 17:19-58.

28. Freeman, J. A., and B. O. Spurlock. 1962. A new epoxy embedment for electron microscopy. J. Cell Biol. 13:437-443.

29. Thomas, P. S. 1980. Hybridization of denatured RNA and small DNA fragments transferred to nitrocellulose. Proc. Natl. Acad. Sci. USA. 77:5201-5205.

30. Southern, E. M. 1975. Detection of specific sequences among DNA fragments separated be gel electrophoresis. J. Mol. Biol. 98:503517.

31. Sager, R., A. Anisowicz, and N. Howell. 1981. Genomic rearrangements in a mouse cell line containing integrated SV40 DNA. Cell. 23:41-50.

32. Yanagi, Y., Y. Yoshikai, K. Leggett, S. P. Clark, I. Aleksander, and T. W. Mak. 1984. A human T cell-specific cDNA clone encodes a protein having extensive homology to immunoglobulin chains. Nature (Lond.). 308:145-149.

33. Hoffman, A. D., B. Banapour, and J. A. Levy. 1985. Characterization of the AIDS-associated retrovirus reverse transcriptase and optimal conditions for its detection in virions. Virology. 147:326-335. 
34. Murray, H. W., B. Y. Rubin, H. Masur, and R. B. Roberts. 1984. Impaired production of lymphokines and immune(gamma) interferon in the acquired immunodeficiency syndrome. N. Engl. J. Med. 310:883-889.

35. Young, N. S., and P. P. Mortimer. 1984. Viruses and bone marrow failure. Blood. 63:729-737.

36. Socinski, M. A., W. B. Ershler, G. Tosato, and R. M. Blease. 1984. Pure red cell aplasia associated with chronic Epstein-Barr virus infection: evidence for T-cell-mediated suppression of erythroid colony forming units. J. Lab. Clin. Med. 104:995-1006.

37. Sarngadharan, M. G., M. Popovic, L. Bruch, Schũpbach, and R. C. Gallo. 1984. Antibodies reactive with human T-lymphotropic retroviruses (HTLV-III) in the serum of patients with AIDS. Science (Wash. DC). 224:506-508.

38. Miyoshi, I., I. Kubonishi, S. Yoshimoto, T. Akagi, Y. Ohtsuki, Y. Shiraishi, K. Nagata, and Y. Hinuma. 1981. Type C virus particles in a cord $\mathrm{T}$ cell line derived by co-culturing normal human cord leukocytes and human leukaemic T cells. Nature (Lond.). 294:770771.

39. Lipton, J. M., and D. G. Nathan. 1983. Annotation: cell-cell interactions in the regulation of erythropoiesis. Br. J. Haematol. 53:361-367.

40. Moretta, A., M. C. Mingari, G. Corte, and L. Moretta. 1982. Receptors for immunoglobulins and activation markers on human $\mathrm{T}$ lymphocytes. Clin. Haematol. 11:697-709.

41. Torok-Storb, B. 1984. T-cell effects on in vitro erythropoiesis: immune regulation and immune reactivity. Aplastic anemia: stem cell biology and advances in treatment. Progress in Clinical and Biological Research. Young, N. S., A. S. Levine, R. K. Humphries, eds. Vol. 148. Alan R. Liss, Inc., New York. 163-172.

42. Steeg, P. S., P. N. Moore, H. M. Johnson, and J. J. Oppenheim. 1982. Regulation of murine macrophage Ia antigen expression by a lymphokine with immune interferon activity. J. Exp. Med. 156:17801783.

43. Kasahara, T., J. J. Hooks, S. S. Dougherty, and J. J. Oppenheim. 1983. IL-2 mediated $\gamma$-interferon production by human T cells and T cell subsets. J. Immunol. 130:1784-1789.

44. Broxmeyer, H. E., L. I. Lu, E. Platzer, C. Feit, L. Juliano, and B. Y. Rubin. 1983. Comparative analysis of the influences of human gamma, alpha and beta interferons on human multipotential, erythroid and granulocyte-macrophage progenitor cells. J. Immunol. 131:1300-1305.

45. Toretsky, J. A., N. T. Shahidi, and J. L. Finlay. 1984. Effects of recombinant human interferon gamma on hematopoietic progenitor cell growth. Exp. Hematol. 14:182-186.

46. Burdach, S., M. Shatsky, and L. Levitt. 1986. The role of the T cell antigen receptor complex in $\gamma$-interferon-induced modulation of erythropoiesis. Blood. 68:138a. (Abstr.)

47. Zoumbos, N. C., P. Gascon, J. Y. Djeu, S. R. Trost, and N. S. Young. 1985. Circulating activated suppressor $\mathrm{T}$ lymphocytes in aplastic anemia. N. Engl. J. Med. 312:257-265.

48. Salahuddin, S. Z., P. D. Markham, S. G. Lindner, J. Gootenberg, M. Popovic, H. Hemmi, P. Sarin, and R. C. Gallo. 1984. Lymphokine production by cultured human $T$ cells transformed by human T-cell leukemia-lymphoma virus-I. Science (Wash. DC). 223:703-706.

49. Callard, R. E., C. M. Smith, C. Worman, D. Linch, J. C. Cawley, and P. C. Beverley. 1981. Unusual phenotype and function of an exparded subpopulation of $\mathrm{T}$ cells in patients with haemopoietic disorders. Clin. Exp. Immunol. 43:497-505.

50. Waldmann, T. A., M. M. Davis, K. F. Bongiovanni, and S. J. Korsmeyer. 1985. Rearrangements of genes for the antigen receptor on $\mathrm{T}$ cells as markers of lineage and clonality in human lymphoid neoplasms. N. Engl. J. Med. 313:776-783.

51. Bertness, V., I. Kirsch, G. Hollis, B. Johnson, and P. A. Bunn.
1985. T cell receptor gene rearrangements as clinical markers of human T cell lymphomas. $N$. Engl. J. Med. 313:534-538.

52. Kalyanaraman, V. S., M. G. Sarngadharan, M. Robert-Guroff, I. Miyoshi, D. Blayney, D. Golde, and R. C. Gallo. 1982. A new subtype of human T-cell leukemia virus (HTLV-II) associated with a T-cell variant of hairy cell leukemia. Science (Wash. DC). 218:571573.

53. Palmer, E. L., R. B. Ramsey, P. F. Feorino, A. K. Harrison, C. Cabradilla, D. P. Francis, M.-C. Poon, and B. L. Evatt. 1984. Human T-cell leukemia virus in lymphocytes of two hemophiliacs with the acquired immunodeficiency syndrome. Ann. Intern. Med. 101:293297.

54. Markham, P. D., S. Z. Salahuddin, B. Macchi, M. RobertGuroff, and R. C. Gallo. 1984. Transformation of different phenotypic types of human bone marrow T-lymphocytes by HTLV-I. Int. $J$. Cancer. 33:13-17.

55. Longo, D. L., E. P. Gelmann, J. Cossman, R. Young, R. C. Gallo, S. O'Brien, and L. A. Matis. 1984. Isolation of HTLV-transformed B-lymphocyte clone from a patient with HTLV-associated adult T-cell leukemia. Nature (Lond.). 310:505-506.

56. Popovic, M., P. S. Sarin, M. Robert-Guroff, V. S. Kalyanaraman, D. Mann, J. Minowada, and R. C. Gallo. 1983. Isolation and transmission of human retrovirus (human T-cell leukemia virus). Science (Wash. DC). 219:856-859.

57. Ho, D. D., T. B. Rota, and M. S. Hirsch. 1984. Infection of human endothelial cells by human T-lymphotropic virus type I. Proc. Natl. Acad. Sci. USA. 81:7588-7590.

58. Clapham, P., K. Nagy, R. Cheingsong-Popov, M. Exley, and R. A. Weiss. 1983. Productive infection and cell-free transmission of HTLV in a nonlymphoid cell line. Science. 222:1125-1127.

59. Amagaski, T., Y. Tomonaga, Y. Yamada, J. Suzuyama, S. Ikeda, K. Kinoshita, and M. Ichimaru. 1985. Adult T-cell leukemia with an unusual phenotype, Leu-2a positive and Leu-3a negative. Blut. 50:209-211.

60. Wachsman, W., D. W. Golde, and I. S. Y. Chen. 1986. HTLV and human leukemia: perspectives 1986. Sem. Hematol. 23:245-256.

61. Bagby, G. C., H. J. Lawrence, and R. C. Neerhout. 1983. T-lymphocyte-mediated granulopoietic failure. N. Engl. J. Med. 309:1073-1078.

62. Hardy, W. D. 1980. Feline leukemia virus diseases. In Feline Leukemia Virus. W. D. Hardy, M. Essex, and A. J. McClelland, editors. Elsevier-North Holland, New York. 3-31.

63. Hankins, W. D., and J. Kaminchik. 1984. Modification of erythropoiesis and hormone sensitivity by RNA tumor viruses. In Aplastic Anemia: Stem Cell Biology and Advances in Treatment. Progress in Clinical and Biological Research. N. S. Young, A. S. Levine, and R. K. Humphries, editors. Vol. 148. A. R. Liss, Inc., New York. 141-152.

64. Pandolfi, F., G. DeRossi, F. Lauria, A. Ranucci, G. Barillari, V. Manzari, G. Semenzato, V. Liso, G. Pizzolo, and F. Aiuti. 1985. Thelper phenotype chronic lymphocytic leukemia and "adult T-cell leukemia" in Italy. Lancet. ii:633-636.

65. Harper, M. E., M. H. Kaplan, L. M. Marselle, S. G. Pahwa, K. J. Chayt, M. G. Sarngadharan, F. Wong-Staal, and R. C. Gallo. 1986. Concomitant infection with HTLV-I and HTLV-III in a patient with T8 lymphoproliferative disease. N. Engl. J. Med. 315:1073-1078.

66. Sohn, C. C., D. W. Blayney, J. L. Misset, G. Mathé, G. Flandrin, E. M. Moran, F. C. Jensen, C. D. Winberg, and H. Rappaport. 1986. Leukopenic chronic $\mathrm{T}$ cell leukemia mimicking hairy cell leukemia: association with human retroviruses. Blood. 67:949-956.

67. Lifson, J. D., G. R. Reyes, M. S. McGrath, B. S. Stein, and E. G. Engleman. 1986. AIDS retrovirus induced cytopathology: giant cell formation and involvement of CD4 antigen. Science (Wash. DC). 232:1123-1127. 